\title{
Conservation planning for Africa's Albertine Rift: conserving a biodiverse region in the face of multiple threats
}

\author{
Andrew J. Plumptre, Sam Ayebare, Deo Kujirakninja and Dan Segan
}

\begin{abstract}
The Albertine Rift is one of Africa's most biodiverse regions, but is threatened by habitat loss as a result of agricultural expansion and human development. Previous studies estimated that $30 \%$ of the region has been lost to agricultural conversion and we estimate here that $33 \%$ is allocated for mining concessions. For conservation planning, we used niche models for species endemic to the Albertine Rift and those that are globally threatened. We assessed where to conserve these species using three scenarios: (1) a baseline assuming equal conservation costs across all grid cells in the study area, (2) a scenario locking in existing protected areas (i.e. always selecting them by default) and assessing which unprotected areas require conservation, and (3) a scenario considering mining planned across the region. Marxan analyses produced similar results for the three scenarios, highlighting the importance of existing protected areas and the value of several community-managed or provincial protected areas in the eastern Democratic Republic of the Congo. The current protected area network covers $134,246 \mathrm{~km}^{2}$ and an additional $64,586 \mathrm{~km}^{2}$ would be required to ensure the conservation of all threatened and endemic species outside the parks and wildlife reserves. However, if trying to avoid mining concessions this increases to $145,704 \mathrm{~km}^{2}$, an area larger than the existing protected areas. Some mining concessions harbour species with a restricted range and would thus need to be protected to ensure the persistence of threatened and endemic fauna and flora. These mining concessions should be challenged by the conservation community.
\end{abstract}

Keywords Albertine Rift, biodiversity, conservation planning, Marxan, mining, niche models, protected areas

Supplementary material for this article is available at doi.org/10.1017/So030605319000218

ANDREW J. Plumptre ${ }^{*}$ (Corresponding author, (D) orcid.org/0000-0002-93334047), Sam Ayebare, Deo Kujirakwinja and Dan Segan Wildlife Conservation Society, 2300 Southern Boulevard, Bronx, New York City, NY 10460, USA E-mail aplumptre@keybiodiversityareas.org

*Also at: Conservation Science Group, Department of Zoology, University of Cambridge, Cambridge, UK, and Key Biodiversity Areas Secretariat, c/o BirdLife International, Cambridge, UK

Received 11 October 2018. Revision requested 3 December 2018.

Accepted 18 February 2019. First published online 24 January 2020.

\section{Introduction}

A frica has been described as the 'last frontier' for development and there are plans to increase foreign investment in the continent (Ohwoso et al., 2002). Most of this global interest is focused on natural resource extraction, supported by major infrastructure development projects planned across Africa (Laurance et al., 2015a). These projects include a growing network of roads (Laurance et al., 2014), pipelines, railways and hydroelectric dams (Laurance et al., 2015b) planned for development. Similarly, mining concessions for both exploration and production cover large parts of Africa, as companies in countries such as China and India (Tull, 2006; Kaplinsky et al., 2007) seek mineral resources for their industries. Mining concessions are being established across the continent, with little thought for environmental impacts. Although investment in Africa can help overcome poverty, it needs to also protect the environmental services that people rely upon and the biodiversity that underpins tourism as a major source of income in many countries. Methods to minimize the impacts of development exist and mostly promote the mitigation hierarchy (BBOP 2010; Saenz et al., 2013). The first component of the hierarchy encourages avoidance of sites with high biodiversity and critical habitats for threatened species, and is the most effective way to minimize impacts (Phalan et al., 2018). Conservation planning can help identify areas to be avoided and locations for potential offsetting activities (Saenz et al., 2013). We show here how such approaches can be used to minimize the impacts of planned mining in one of Africa's most biodiverse regions.

Africa's Western Rift Valley, the Albertine Rift, has been designated an endemic bird area (Stattersfield et al., 1998), a Global 200 Priority Ecoregion (Olson \& Dinerstein, 1998; Burgess et al., 2004) and part of the Eastern Afromontane Hotspot (Brooks et al., 2004; Plumptre et al., 2004). The richness of vertebrate and plant taxa has been documented previously (Plumptre et al., 2003, 2007) and in 2003 there were 5,793 plant species and 1,757 terrestrial vertebrate species reported for the region. More thorough surveys, identification of new species and additional records for plants have increased these numbers to 6,568 plants and 1,833 terrestrial vertebrates (Plumptre et al., 2017), and more species are being discovered and described, particularly amphibians, reptiles and plants. This region has the highest diversity of terrestrial vertebrates in Africa, containing $>50 \%$ and $40 \%$ 
of Africa's bird and mammal species, respectively. It also harbours more endemic and globally threatened vertebrates than any other part of the continent (Plumptre et al., 2007). At least 980 species of mammals, birds, reptiles, amphibians, fish, butterflies, dragonflies and plants are endemic to the Albertine Rift. Of the terrestrial vertebrates and plants 15 species are categorized as Critically Endangered, 34 as Endangered and 99 as Vulnerable on the IUCN Red List (Plumptre et al., 2017). Many taxa have not been fully assessed or are categorized as Data Deficient (poorly known and potentially threatened because they are rare and with a limited distribution; Bland et al., 2015), so the true number of threatened species may be higher. Protected areas in the region include four World Heritage Sites (Rwenzori Mountains, Bwindi Impenetrable, Kahuzi Biega and Virunga National Parks), a Man and the Biosphere Reserve (Queen Elizabeth National Park) and three Ramsar sites (Lake George and Edward wetlands, Virunga Park, and the Nile delta of Lake Albert at Murchison Falls National Park; Fig. 1).

There is a strong positive correlation between biodiversity and human population density across Africa (Burgess et al., 2007). The Albertine Rift contains some of the continent's highest human population densities (Burgess et al., 2007; Cordeiro et al., 2007), with up to 1,000 people per $\mathrm{km}^{2}$ in south-west Uganda and Rwanda (Plumptre et al., 2017). As a result, the biodiversity is under threat from habitat loss and degradation, and from hunting. An estimated $30 \%$ of the Albertine Rift has been converted to farmland or settlement (Ayebare et al., 2018) as people take advantage of the rich volcanic soils around the rift valley. Recent mining developments for minerals, oil and gas are further increasing the threats to biodiversity in the region (Johnson, 2007; Plumptre et al., 2016a). Governments in the five countries of the Albertine Rift have established mining concessions across much of their land, most of which are currently in the exploration phase. In several countries these exploration areas overlap with protected areas, and in the eastern Democratic Republic of the Congo (DRC) the extraction of minerals has fuelled armed conflict and insecurity (Maystadt et al., 2014).

During 2001-2004 a process to develop a strategic framework plan for the Albertine Rift was implemented (ARCOS, 2004), involving international and national NGOs, universities, local communities and protected area authorities. This process identified six key landscapes of conservation importance that would protect many of the endemic and threatened species: (1) the Murchison-Semliki Landscape, western Uganda, (2) the Greater Virunga Landscape, straddling the borders of south-west Uganda, northern Rwanda and eastern DRC, (3) the Maiko-Itombwe Landscape, eastern DRC, (4) the Congo-Nile Divide Landscape, straddling the border of southern Rwanda and northern Burundi, (5) the Greater Mahale Landscape, western Tanzania, and (6) the Marungu-Kabobo Landscape, south-eastern DRC.

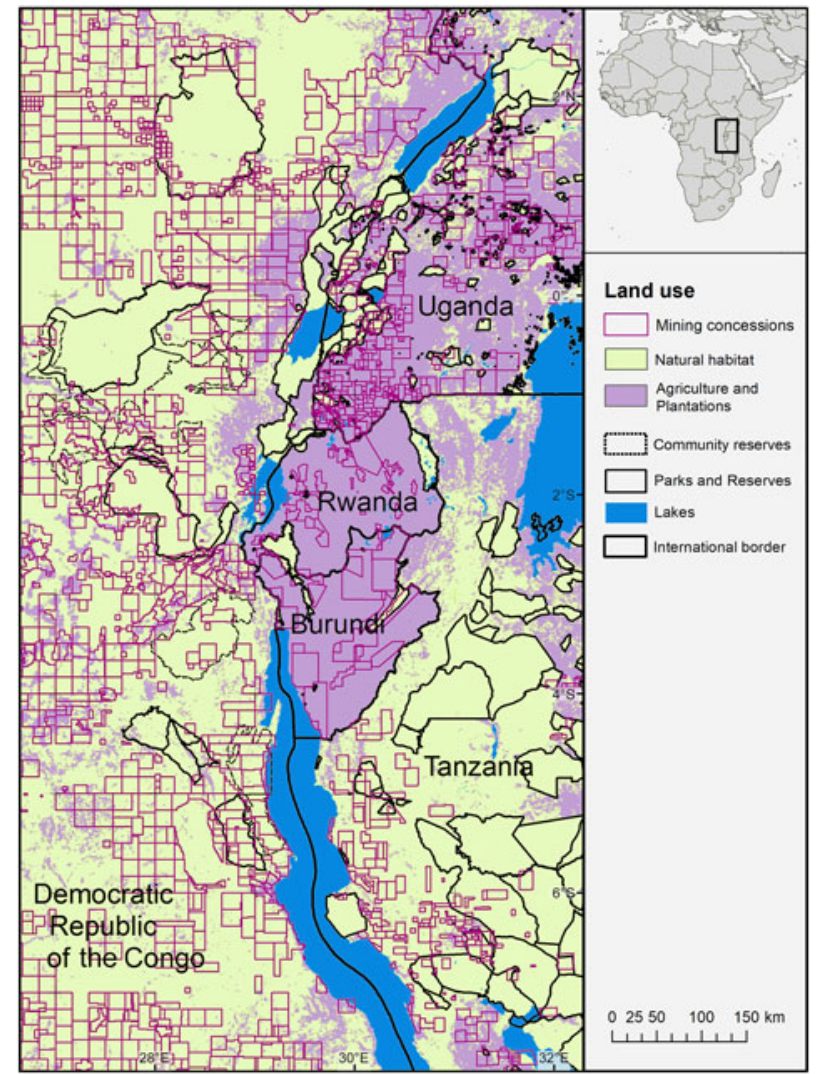

FIG. 1 Protected areas in the Albertine Rift region where we assessed the optimum areas for conservation, showing extent of agriculture and mining concessions.

However, the strategic framework plan did not assess the critical sites that would be needed to conserve all endemic and threatened species in the Albertine Rift region because data to make this assessment were not available at that time. Since 2004 the Wildlife Conservation Society and partners have surveyed many areas of remaining natural habitat to support more rigorous conservation planning across the region.

Conservation planning approaches provide methods to assess where to focus conservation efforts to ensure persistence of all species, while minimizing the area that needs to be set aside or the cost associated with these efforts (Moilanen et al., 2009). The programmes Zonation (Moilanen \& Kujala, 2006), Marxan (Possingham et al., 2000; Ball et al., 2009) and C-Plan (Pressey et al., 2005) are commonly used for such planning. These methods aim to efficiently invest conservation resources by either identifying the minimum cost incurred to achieve a suite of conservation targets or maximize return on a given investment. Planners use these tools by initially setting target amounts for each of the conservation features (in our study, species), and then dividing the landscape into planning units within which the species composition, abundance or contribution towards the conservation targets can be 
calculated. Once the cost of achieving the target in each planning unit has been calculated, the analysis aims to identify the more frequently selected cells (i.e. those with unique assemblages of species) and other planning units required to ensure sufficient area is conserved for each cell. High quality species distribution data are required for these analyses. Here, we use these planning methods to assess where to target conservation investment across the Albertine Rift, to ensure its threatened and endemic species will survive in the long term despite the threats from agriculture and mining concessions.

\section{Methods}

We modelled species ranges for 162 endemic and 32 globally threatened species using the methods reported in detail in Ayebare et al. (2018). We summarize the methods here.

\section{Biodiversity data}

We compiled georeferenced biodiversity data from surveys carried out across the Albertine Rift by the Wildlife Conservation Society during 1997-2016. In addition, we obtained species distribution data for certain species from the Global Biodiversity Information Facility (GBIF, 2015), Chicago Field Museum (Chicago, USA), Tanzania Mammal Atlas (Tanzania Wildlife Research Institute, Arusha, Tanzania), University of Texas at El Paso (El Paso, USA), Centre de Recherche en Sciences Naturelles de Lwiro (Lwiro, DRC), and Missouri Botanical Garden (St Louis, USA) to provide additional georeferenced records for the endemic and threatened (according to the IUCN Red List; IUCN, 2015) species of the Albertine Rift. We used a total of 32,854 presence records in the modelling process: birds $(8,765)$, large mammals $(17,345)$, small mammals $(1,448)$, plants $(4,473)$, reptiles $(436)$ and amphibians $(387)$.

\section{Modelling species distributions}

We used a maximum entropy species distribution approach to model areas of suitable habitat (Maxent 3.3.3e; Phillips et al., 2006). We selected Maxent because it requires only species' presence data and environmental predictor variables and performs as well or better than other species distribution modelling techniques (Elith et al., 2006, Phillips et al., 2006). We used Maxent default parameters (auto features, convergence threshold of o.0ooo1, maximum number of background points $=10,000$, regularization multiplier $=1$ ) to fit most of the models. However, one-third of the species (10-20 records) were fitted using hinge features, which are functions for piecewise linear splines and fit models closely related to generalized additive models (Elith et al., 2011). We selected 17 potential predictor variables for the models relating to climate (9), topology (4), hydrology (2), geology (1) and human activities (1) that were thought likely to influence species distributions (Ayebare et al., 2018; Supplementary Table 1). These were all raster maps of 1 $\mathrm{km}^{2}$ cell resolution. We clipped all predictor variables to the area of interest and obtained a pairwise Pearson correlation between predictor variables using ENMTOOLs (Warren et al., 2010). To minimize the effect of multicollinearity and overfitting, we retained only variables with $<0.75$ correlation.

We tested model accuracy using the area under the receiver operating characteristic curve test statistic (Fielding \& Bell, 1997; Freeman \& Moisen, 2008) and selected model outputs with values $\geq 0.8$ for the final analysis (Manel et al., 2001). We used $75 \%$ of the occurrence records for training and $25 \%$ for testing. After assessing model accuracy, we fitted the final models for all species using all occurrence records. To convert the predicted habitat suitability from a continuous logistic output format into a binary (presence/ absence) output, we used the maximum training sensitivity plus specificity threshold rule (Liu et al., 2005), which minimizes the mean error rate for positive observations and the error rate for negative observations (Freeman \& Moisen, 2008).

\section{Loss of wildlife habitat to agriculture}

The predicted species ranges included areas in which natural habitats had been replaced by agriculture, plantations or settlements. Using a combination of the GlobCover 2009 land cover map (Arino et al., 2012) and maps of different landscapes produced by the Wildlife Conservation Society from satellite images, we estimated the extent of humanmodified areas across the Albertine Rift and clipped species ranges to exclude these areas (Ayebare et al., 2018).

\section{Mapping of mining concessions}

To create maps of mining concessions we used mining concession layers from MOXI mining cadastre maps (MOXI, 2016), digitizing the mining concessions from images as the data were not available to download as a shapefile. We obtained further information on mining concessions from contacts within government ministries in the various countries.

\section{Scenarios for conservation planning}

Marxan (Possingham et al., 200o) uses simulated annealing to estimate the near-optimal solution to a conservation planning problem. We overlaid $5 \mathrm{~km}^{2}$ hexagonal cells across the entire Albertine Rift extent, covering 993,044 $\mathrm{km}^{2}$. We assigned a cell to a species' modelled range if $>50 \%$ of the cell was predicted to contain the species. Target amounts 
for each species were set in Marxan, aiming to ensure the conservation of a viable population for each species. For species that are relatively abundant where they occur we selected $30 \%$ of the species' current range within the Albertine Rift extent as a target. Some species such as elephants, apes and large carnivores require large areas of habitat to maintain viable populations. For these species, or those that occur at low density or within a restricted area, we selected higher percentages of cells (40-100\%) to ensure their needs would be met in the final conservation plan. We analysed the data for all species, and for (1) only globally threatened species (endemic and non-endemic; IUCN, 2015), and (2) only endemic species. Marxan requires a boundary length modifier value that can be used to minimize boundary length and thereby identify results that are more compact (lower boundary:area ratio). Higher values of this modifier generally result in larger areas and more expensive solutions. We set the boundary length modifier value at 0.01 to apply minimal constraint as we were interested in the least costly solutions.

We ran Marxan 100 times to obtain a selection frequency for each cell in the Albertine Rift extent. We analysed three scenarios: the first scenario assumed the cost of conservation to be equal in all cells and thus identified the minimum area required to conserve all species. This is useful as a baseline to compare with the results of other scenarios. The second scenario locked in existing national parks and reserves, meaning these areas were always selected by default. Proposed community-managed or existing provincial reserves were not locked into the analysis because these are legally less secure and we wanted to assess their importance in the overall conservation plan. Provincial reserves established in 2016-2017, including Itombwe Reserve (Kujirakwinja et al., 2019), Kabobo Reserve, Ngandja Reserve, and community reserves between the Kahuzi Biega and Maiko National Parks in eastern DRC, were not locked in (Plumptre et al., 2017). As well as always selecting cells within existing parks and reserves, the Marxan analysis in this second scenario identified additional cells outside protected areas that met the targets. This scenario is more realistic than the first because it recognizes conservation investments made to-date. The third scenario built upon the second by preferentially weighting cells within protected areas but also considering the development needs of the affected countries, specifically aiming to avoid existing or potential mining concessions. Because some mining concessions occur within protected areas we did not lock in the protected areas in this analysis. Instead, we weighted costs according to whether a cell was within a mining concession or protected area using the formula:

$$
C=6+\left(2 A \times P_{m}\right)-\left(A \times P_{p}\right)
$$

where $C$ is the relative conservation cost for a cell, $A$ is the area of the cell $\left(5 \mathrm{~km}^{2}\right.$, except for cells at the edge of a lake),
$P_{m}$ is the proportion of the cell within a mining concession and $P_{p}$ is the proportion within a protected area. Applying this formula means that if a cell contained no mining concession or protected area, conserving it cost 6 units; conserving a cell entirely within a mining concession and no protected area cost 16 units; a cell entirely within a protected area and no mining concession cost 1 unit; and conserving a cell that was entirely within a mining concession and a protected area cost 11 units. This effectively lowers the cost of conservation in protected areas and increases the cost in mining concessions, whether these occur within or outside protected areas.

\section{Results}

We included a total of 243 endemic and globally threatened species as conservation targets in the Marxan analyses, with ranges modelled for 162 endemic and 32 globally threatened (not endemic) species, and 49 endemic species with only point locations in cells. The latter species were incorporated in the Marxan analysis as presences within the $5 \mathrm{~km}^{2}$ grid cells, and because there were few points $(<10)$ for each species, we set a target of $100 \%$ in the Marxan analyses.

\section{Where to conserve if costs are equal in all cells}

This scenario assumes conservation costs are equal for all cells and provides a baseline assessment that shows where all threatened and endemic terrestrial vertebrates and plants would be conserved at minimum cost. Even with costs assumed equal across all cells, the analysis showed that most of the important areas fall within the existing protected area network (Fig. 2). Key areas identified outside protected areas included the highlands between Itombwe and Kabobo Massifs, forested areas around Tayna and Kisimba-Ikobo Reserves in DRC, and woodlands and Sitebi Highlands east of Mahale Mountains National Park in Tanzania. There was little variation in results between the assessments of endemic vs globally threatened species (Supplementary Fig. 1).

\section{Where to conserve outside existing national parks and reserves}

In this scenario existing parks and reserves were locked into the analysis to identify additional areas required to conserve all threatened and endemic terrestrial vertebrates and plants outside the existing protected area system. The analysis showed that the Tayna and Kisimba-Ikobo Reserves west of Lake Edward and the highlands of the Itombwe Massif and ridge down to the Kabobo Massif are important areas outside the existing parks and reserves in DRC (Fig. 3). The areas east of Mahale Mountains National Park 


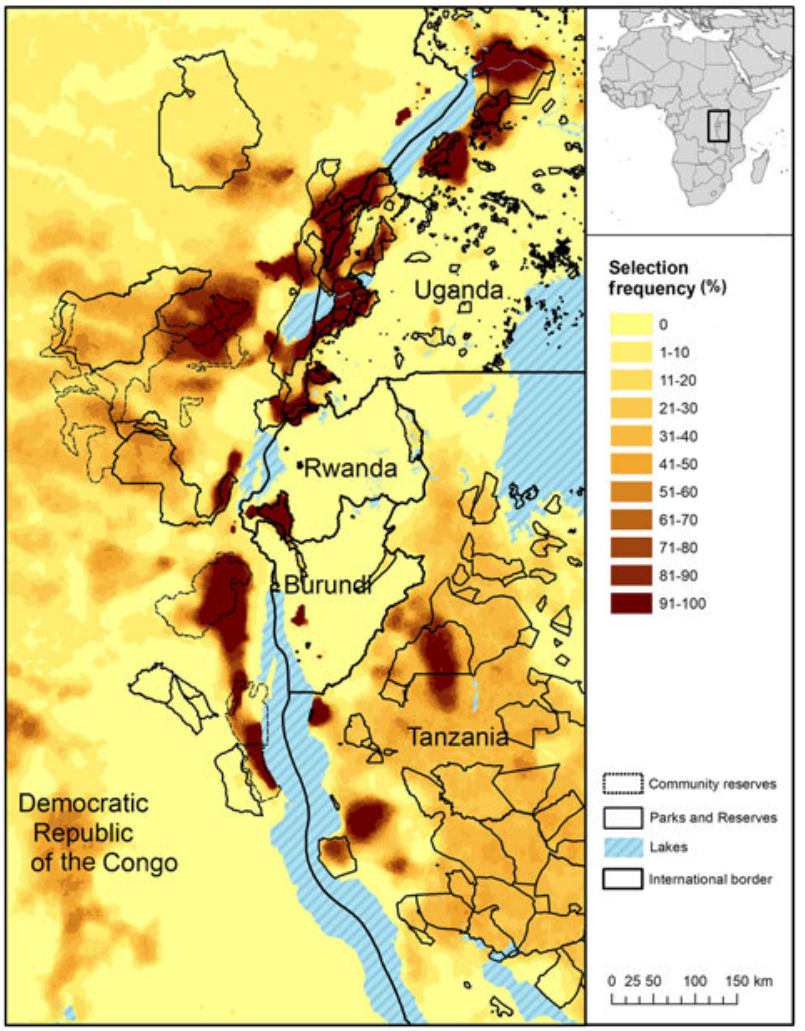

FIG. 2 Scenario 1: selection frequency of $5 \mathrm{~km}^{2}$ cells assuming equal conservation costs across all cells, aiming to conserve all threatened and endemic terrestrial vertebrates and plants in the region.

(including Ntakata forest and the Sitebi Highlands) in western Tanzania were also identified as important as they contain the Kungwe apalis Apalis argentea, African elephant Loxodonta africana and African wild dog Lycaon pictus. The results of this analysis were used to help establish the Itombwe, Ngandja and Kabobo Reserves as provincial reserves in eastern DRC. The results for globally threatened vs endemic species are very similar (Supplementary Fig. 2).

\section{Where to conserve in the face of future developments}

This scenario aimed to balance the existence of protected areas with the planned mining developments in the Albertine Rift to assess where conservation should be targeted considering both of these factors. Where cells are still selected within mining concessions it shows that these sites are critical for certain species and mining should ideally not proceed here (Fig. 4). Maps of mining concessions for the region show that $326,749 \mathrm{~km}^{2}(33 \%)$ of the area we focused on is allocated to existing or proposed exploration concessions. Patterns for threatened vs endemic species were similar (Supplementary Fig. 3).

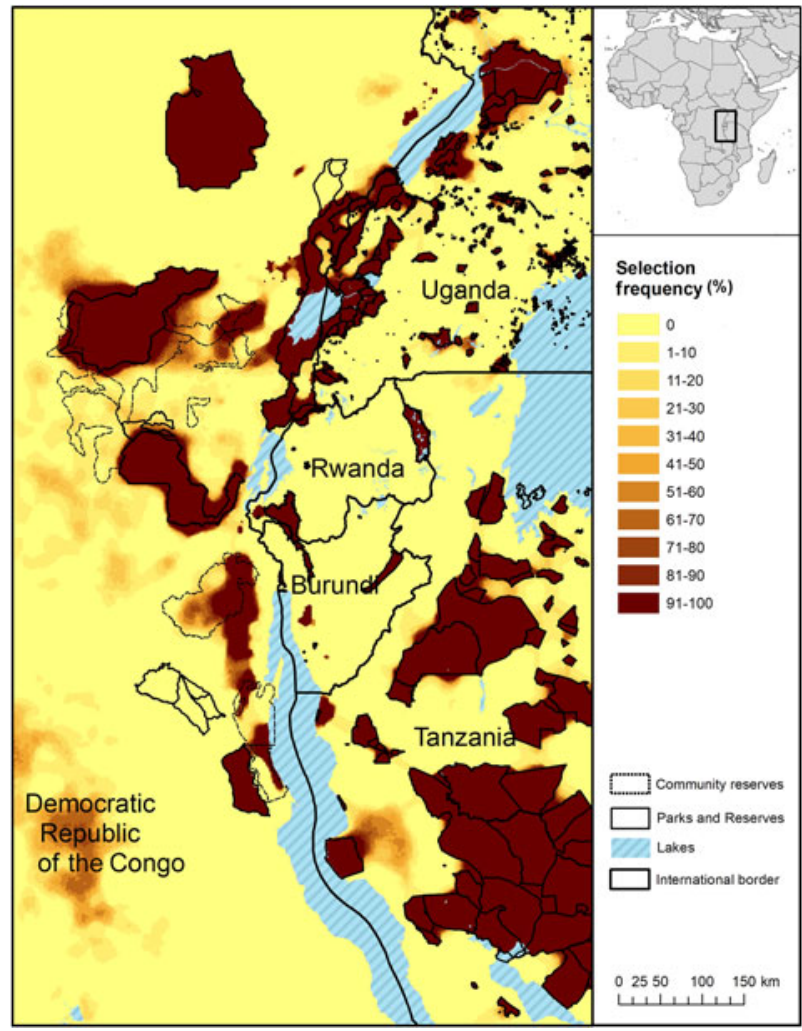

FIG. 3 Scenario 2: selection frequency of $5 \mathrm{~km}^{2}$ cells, locking in (i.e. always selecting) all cells within existing parks and reserves (but excluding existing or proposed community managed protected areas, shown with a dashed border).

\section{Area requirements outside existing protected areas}

We evaluated the area designated as irreplaceable (selected $100 \%$ of the time) that occurred within or outside protected areas (Table 1). Under scenario 2 the irreplaceable area within parks and reserves is expectedly high because these are locked into the analysis and are always selected by default. The area of irreplaceable sites outside protected areas was similar under scenario 1 (equal cost) and scenario 3 (avoiding mining concessions) but larger for scenario 2 (protected areas always selected), indicating that some species of conservation concern occur primarily outside protected areas. In terms of the area required for the most cost efficient solution under the different scenarios, scenario 1 (conservation cost equal for all cells) required the smallest area. Locking in the protected areas (scenario 2) increased the total area required by $41 \%$, but the area that needs to be conserved outside protected areas is smallest in this scenario. The most cost effective solution under scenario 3 (avoiding mining concessions and preferentially selecting cells in protected areas) increased the area required by $67 \%$. The percentage of the Albertine Rift extent required to conserve all endemic and threatened species ranged from $14.26 \%$ under scenario 1 to $23.85 \%$ under scenario 3 (Table 1 ). 


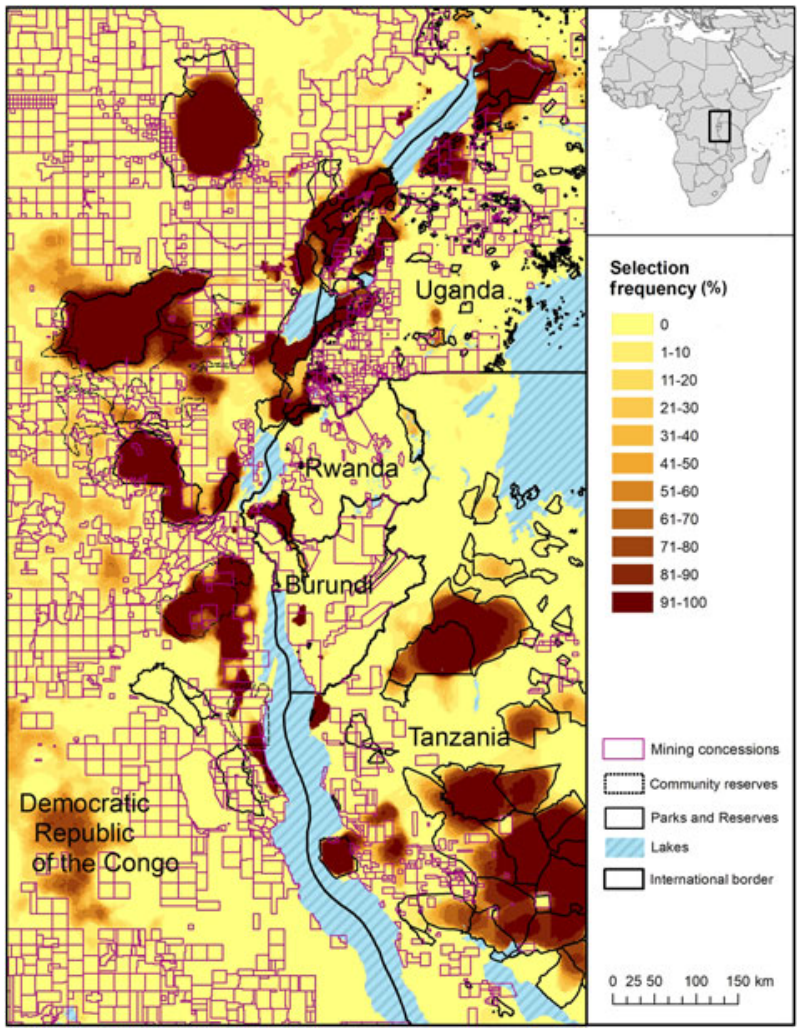

FIG. 4 Scenario 3: selection frequency of $5 \mathrm{~km}^{2}$ cells, with mining concessions being more, and existing parks and reserves less costly to conserve.

\section{Discussion}

The Albertine Rift region is under pressure from agricultural expansion linked to high human population densities, and from potential developments, particularly mining concessions. Other developments (e.g. roads, railways, powerlines, oil pipelines and urban expansion) are also likely in this region, but these were beyond the scope of this study. Here, we considered existing habitat loss to agriculture and existing mining concessions as the main threats to species conservation. These factors currently have the biggest impact in the Albertine Rift region because they are widespread and can occur even in remote forests. We could not assess artisanal mining because it is mapped incompletely across the Albertine Rift. Regulations for small-scale mining exist in all countries in the region but are often not enforced. However, given the lower impact of such mining activities (except for the hunting of some large mammal species by miners for food) they are probably less harmful to most endemic and threatened species in the Albertine Rift than industrial mining. Gorillas and elephants are most at risk from artisanal mining because they are hunted for both meat and trophies (Plumptre et al., 2016b). Our analyses showed that it is possible to conserve all endemic and threatened species in the Albertine Rift region while allowing for most of the potential large-scale future mining developments. However, taking into account the existing protected area network in the region, the cost and land requirements to achieve this are considerably higher than in a scenario that would allow a complete redesign of protected areas, without relying on any previous designations. Although most species can be preserved outside existing mining concessions, there are some areas where conservation has to take place within planned mining concessions to achieve the conservation targets set in Marxan. These include proposed mining concessions within Kahuzi Biega National Park, Tayna Reserve, Itombwe and Kabobo Massifs and concessions around Bugoma Forest Reserve in Uganda (Fig. 4). Mining concessions in these locations should be contested and mining companies should avoid them as part of any mitigation hierarchy.

Taking into account the existing parks and reserves in the Albertine Rift and avoiding placing conservation efforts in mining concessions (comparing the percentage area of the best solution in scenarios 2 and 3), an additional 3.8\% of the region's area needs to be designated for conservation

TABLE 1 Results of Marxan analyses for conservation planning in the Albertine Rift region, showing the area of irreplaceable cells (selected in $100 \%$ of model runs) and area of the best (most cost efficient) solution, separated by areas inside and outside existing parks and reserves, for three modelling scenarios. Scenario 1 assumes equal conservation costs across all grid cells, scenario 2 locks in (i.e. always selects) cells in existing protected areas, and scenario 3 avoids mining concessions and prefers existing protected areas. The best solution's total area required for conservation and the area required outside existing protected areas are also given as per cent of the Albertine Rift extent.

\begin{tabular}{lrr}
\hline & Scenario 1 & Scenario 2 \\
\hline Inside protected areas & & \\
Area of irreplaceable sites $\left(\mathrm{km}^{2}\right)$ & 10,798 & 134,246 \\
Area of best solution $\left(\mathrm{km}^{2}\right)$ & 55,181 & 134,246 \\
Outside protected areas & & 45,398 \\
Area of irreplaceable sites $\left(\mathrm{km}^{2}\right)$ & 8,504 & 22,744 \\
Area of best solution $\left(\mathrm{km}^{2}\right)$ & 86,391 & 64,586 \\
Total area of best solution $\left(\mathrm{km}^{2}\right)$ & 141,572 & 198,832 \\
Total area of best solution $(\%$ of Albertine Rift extent) & 14.26 & 20.02 \\
Area of best solution outside protected areas (\% of Albertine Rift extent) & 8.70 & 6.50 \\
\hline
\end{tabular}


to preserve all threatened and endemic species when avoiding mining concessions. Existing protected areas have been established not only to conserve endemic and threatened species, but also to provide ecosystem services such as tourism revenue, and substantial changes to these areas are unlikely. However, conserving all threatened and endemic species and avoiding mining concessions requires an additional $8.2 \%$ of the Albertine Rift extent to be conserved outside protected areas, compared to a scenario that does not seek to avoid mining concessions $(14.7 \%$ vs $6.5 \%$; Table 1$)$. This would be economically challenging given the high human population densities in the area. Some mining concessions are not avoided by the Marxan analysis despite increased costs, implying that these sites are critical for one or more species of conservation concern (Fig. 4). These concessions should be contested and mining companies should avoid them. However, if mining is to go ahead the companies involved should minimize impacts on endemic and threatened species as far as possible and offset residual impacts elsewhere in the Albertine Rift. Offset sites should be those outside protected areas identified as important for the conservation of endemic and threatened species (Fig. 4).

Conservation sites that were not locked in as protected areas (community or provincial reserves) and that were consistently selected by the analyses include the Tayna Reserve, Kisimba-Ikobo Reserve, Itombwe Reserve, Kabobo Provincial Reserve, and Ngandja Provincial Reserve in eastern DRC. Tayna and Kisimba Reserves are important for populations of Grauer's cuckoo shrike Ceblepyris graueri and Allanblackia kimbiliensis (Clusiaceae). Itombwe Reserve contains several endemic or near-endemic species (Kujirakwinja et al., 2019) including the Itombwe river frog Phrynobatrachus asper, Itombwe golden frog Chrysobatrachus cupreonitens, Congo bay owl Phodilus prigoginei and Itombwe nightjar Caprimulgus prigoginei. Kabobo and Ngandja Reserves also harbour several endemic species including Willard's horseshoe bat Rhinolophus willardi, wild ginger Aframomum ngamikkense (Zingiberaceae; Fischer et al., 2017), Kabogo myosorex Myosorex kabogoensis and Kabogo crocidura Crocidura lwiroensis (Kerbis Peterhans et al., 2013). These sites have been recognized for their conservation importance but require additional protection or upgrading to national reserves.

Other sites that were consistently selected outside protected areas included the Sitebi Highlands east of Mahale Mountains National Park in western Tanzania, the escarpment between Itombwe Reserve and Ngandja Reserve, and the forest between Tayna Reserve and Maiko National Park in DRC. Although many of these sites will protect some species that also occur in the neighbouring reserves, the Sitebi Highlands are particularly important as they contain several endemic plants, 13 endemic butterfly species (Kielland, 1990) and the Kungwe apalis Apalis argentea (Moreau, 1943). Projects in this region tend to focus on the chimpanzee Pan troglodytes but rarely consider the other taxa which are more threatened. This area requires a conservation project focused on the wider biodiversity of the region and should be better protected (Plumptre et al., 2017).

These results show that the existing protected area network is relatively well placed and is conserving many of the threatened and endemic species of this highly biodiverse region. However, an additional $6.5 \%$ of land is needed to adequately protect all species of conservation concern. For many species these additional areas may not need to be designated as protected areas but could be managed with other effective area-based conservation measures, provided the habitat is maintained for the species. Figure 3 shows where conservation efforts should focus outside protected areas (see also areas listed above). Conservation practitioners and the governments of the region should work with local communities to ensure these sites are managed together with the existing protected areas and that mining concessions are not allocated there.

Acknowledgements We thank the John D. and Catherine T. MacArthur Foundation (Grant: 97201), the U.S. Fish \& Wildlife Service (Grant: F13AP00680), U.S. Agency for International Development/CAFEC program (AID-660-A-13-00010-64788) and Wildlife Conservation Society (WCS) for funding; Eli Greenbaum (University of Texas at El Paso), Julian Kerbis Peterhans and John Bates (Chicago Field Museum) and Charles Foley and Tim Davenport (Tanzania Mammal Atlas) for providing point location data; and James Watson for supporting DS and advising on analyses.

Author contributions Study conception, fundraising, model revisions, writing: AP; species distribution models for endemic species: SA; data collection and compilation: DK; initial analyses in Marxan: DS.

\section{Conflict of interest None.}

Ethical standards This research abided by the Oryx guidelines on ethical standards.

\section{References}

ARCOS (2004) A Framework for Conservation in the Albertine Rift: 2004-2030. Albertine Rift Conservation Society, Kigali, Rwanda.

Arino, O., Ramos Perez, J.J., Kalogirou, V., Bontemps, S., Defourny, P. \& Van Bogaert, E. (2012) Global Land Cover Map for 2009 (GlobCover 2009). doi.pangaea.de/10.1594/ PANGAEA.787668 [accessed 14 October 2019].

Ayebare, S., Plumptre, A.J., Kujirakwinja, D. \& Segan, D. (2018) Conservation of the endemic species of the Albertine Rift under future climate change. Biological Conservation, 220, 67-75.

Ball, I.R., Possingham, H.P. \& Watts, M. (2009) Marxan and relatives: software for spatial conservation prioritisation. In Spatial Conservation Prioritisation: Quantitative Methods and Computational Tools (eds A. Moilanen, K.A. Wilson \& H.P. Possingham), pp. 185-195. Oxford University Press, Oxford, UK. 
BBOP (Business and Biodiversity Offset Programme) (2010) Biodiversity Offsets and the Mitigation Hierarchy: a Review of Current Application in the Banking Sector. Report by BBOP, UN Finance Initiative and PricewaterhouseCoopers LLP. unepfi.org/ publications/banking-publications/biodiversity-offsets-and-themitigation-hierarchy-a-review-of-current-application-in-thebanking-sector [accessed 14 October 2019].

Bland, L.M., Collen, B., Orme, C.D.L. \& Bielby, J. (2015) Predicting the conservation status of data-deficient species. Conservation Biology, 29, 250-259.

Brooks, T., Hoffmann, M., Burgess, N., Plumptre, A., Williams, S., Gereau, R.E. et al. (2004) Eastern Afromontane. In Hotspots Revisited: Earth's Biologically Richest and Most Endangered Ecoregions. 2nd edition (eds R.A. Mittermeier, P. Robles-Gil, M. Hoffmann, J.D. Pilgrim, T.M. Brooks, C.G. Mittermeier, J.L. Lamoreux \& G. Fonseca), pp. 241-242. University of Chicago Press, Chicago, USA.

Burgess, N.D., Balmford, A., Cordeiro, N.J., Fjelds Å, J., Küper, W., RAнвек, C. et al. (2007) Correlations among species distributions, human density and human infrastructure across the high biodiversity tropical mountains of Africa. Biological Conservation, 134, 164-177.

Burgess, N.D., Hales, J.D., Underwood, E., Dinerstein, E., Olson, D., ItouA, I. et al. (2004) Terrestrial Ecoregions of Africa and Madagascar. Island Press, Washington, DC, USA.

Cordeiro, N.J., Burgess, N.D., Dovie, D.B.K., Kaplin, B., Plumptre, A.J. \& Marrs, R. (2007) Conservation in areas of high population density in sub-Saharan Africa. Biological Conservation, 134, 155-163.

Elith, J., Graham, C.H., Anderson, R.P., Dudik, M., Ferrier, S., Guisan, A. et al. (2006) Novel methods improve prediction of species' distributions from occurrence data. Ecography, 29, 129-151.

Elith, J., Phillips, S.J., Hastie, T., Dudík, M., Chee, Y.E. \& Yates, C.J. (2011) A statistical explanation of MaxEnt for ecologists. Diversity and Distributions, 17, 43-57.

Fielding, A.H. \& BeLl, J.F. (1997) A review of methods for the assessment of prediction errors in conservation presence/absence models. Environmental Conservation, 24, 38-49.

Fischer, E., Kirunda, B., Ewango, C., Leal, M., Kujirakwinja, D., Bamba, A. \& Plumptre, A.J. (2017) A new species of Aframomum (Zingiberaceae) from D.R. Congo. Phytotaxa, 298, 277-282.

Freeman, E.A. \& Moisen, G. (2008) A comparison of the performance of threshold criteria for binary classification in terms of predicted prevalence and kappa. Ecological Modeling, $217,48-58$.

GBif (Global Biodiversity Information Facility) (2015) GBIF Occurrence Download. gbif.org [accessed 2015].

IUCN (2015) The IUCN Red List of Threatened Species. Version 2015-3. iucnredlist.org [accessed 9 February 2016].

Johnson, L. (2007) Assessing the Impacts of Energy Developments and Developing Appropriate Mitigation in the Uganda Portion of the Albertine Rift. Unpublished report to Uganda Wildlife Authority. Wildlife Conservation Society, Kampala, Uganda.

Kaplinsky, R., D. McCormick \& M. Morris (2007) The Impact of China on Sub-Saharan Africa. Working paper series, 291. Institute of Development Studies, Brighton, UK.

Kerbis Peterhans, J., Fahr, J., Huhndorf, M.H., Plumptre, A.J., Hutterer, R., Kaleme, P. \& Ndara, B. (2013) Mammals, other than bats, from the Misotshi-Kabogo Highlands (eastern Democratic Republic of Congo), with the description of two new species (Mammalia: Soricidae). Bonn Zoological Bulletin, 62, 203-219. Kielland, J. (1990) Butterflies of Tanzania. Hill House Publishers, Melbourne, Australia, and London, UK.
Kujirakwinja, D., Plumptre, A.J., Twendilonge, A., Mitamba, G., Mubalama, L., Wasso, J. et al. (2019) Establishing the Itombwe Natural Reserve: science, participatory consultations and zoning. Oryx, 53, 49-57.

Laurance, W.F., Gopalasamy, R.C., Sloan, S., O'Connell, C.S., Mueller, N.D., Goosem, G. et al. (2014) A global strategy for road building. Nature, 513, 229-232.

Laurance, W.F., SLOAN, S., Weng, L. \& SAyer, J.A. (2015a) Estimating the environmental costs of Africa's Massive "Development Corridors". Current Biology, 25, 3202-3208.

Laurance, W.F., Peletier-Jellema, A., Geenen, B., Koster, H., Verweij, P., VAn Dijck, P. et al. (2015b) Reducing the global environmental impacts of rapid infrastructure expansion. Current Biology, 25, R259-R262.

Liu, C., Berry, P.M., Dawson, T.P. \& Pearson, R.G. (2005) Selecting thresholds of occurrence in the prediction of species distributions. Ecography, 28, 385-393.

Manel, S., Williams, H.C. \& Ormerod, S.J. (2001) Evaluating presence-absence models in ecology: the need to account for prevalence. Journal of Applied Ecology, 38, 921-931.

Maystadt, J.-F., De Luca, G., Sekeris, P.G. \& Ulimwengu, J. (2014) Mineral resources and conflicts in DRC: a case of ecological fallacy? Oxford Economic Papers, 66, 721-749.

Moilanen, A. \& Kujala, H. (2006) The Zonation Conservation Planning Framework and Software $x$ 1.o User Manual. Edita, Helsinki, Finland. helsinki.fi/BioScience/ConsPlan [accessed 18 July 2019].

Moilanen, A., Wilson, K.A. \& Possingham, H.P. (2009) Spatial Conservation Prioritisation: Quantitative Methods and Computational Tools. Oxford University Press, Oxford, UK.

Moreau, R.E. (1943) A contribution to the ornithology of the east side of Lake Tanganyika. Ibis, 85, 377-412.

MOXI (2016) Maps of Extractive Industries. sites.google.com/site/ mymoxi/home [accessed 2016].

Olson, D.M. \& Dinerstein, E. (1998) The global 200: a representation approach to conserving the Earth's most biologically valuable ecoregions. Conservation Biology, 12, 502-515.

Owhoso, V., Gleason, K.C., Mathur, I. \& Malgwi, C. (2002) Entering the last frontier: expansion by US multinationals to Africa. International Business Review, 11, 407-430.

Phalan, B., Hayes, G., Brooks, S., Marsh, D., Howard, P., Costelloe, B. et al. (2018) Avoiding impacts on biodiversity through strengthening the first stage of the mitigation hierarchy. Oryx, 52, 316-324.

Phillips, S.J., Anderson, R.P. \& Schapire, R.E. (2006) Maximum entropy modeling of species geographic distributions. Ecological Modelling, 190, 231-259.

Plumptre, A.J., Behangana, M., Davenport, T., Kahindo, C., Kityo, R., Ndomba, E. et al. (2003) The Biodiversity of the Albertine Rift. In Albertine Rift Technical Reports No. 3, pp. 105, Wildlife Conservation Society, New York, USA.

Plumptre, A.J., Davenport, T.R.B., Behangana, M., Kityo, R., Eilu, G., Ssegawa, P. et al. (2004) Albertine Rift. In Hotspots Revisited: Earth's Biologically Richest and Most Endangered Ecoregions. 2nd edition (eds R.A. Mittermeier, P. Robles-Gil, M. Hoffmann, J.D. Pilgrim, T.M. Brooks, C.G. Mittermeier, J.L. Lamoreux \& G. Fonseca), pp. 255-262. University of Chicago Press, Chicago, USA.

Plumptre, A.J., Davenport, T.R.B., Behangana, M., Kityo, R., Eilu, G., Ssegawa, P. et al. (2007) The biodiversity of the Albertine Rift. Biological Conservation, 134, 178-194.

Plumptre, A.J., Prinsloo, S., Ayebare, S. \& Nangendo, G. (2016a) Documentation of Existing and Potential Oil/Geothermal Projects, Mapping their Likely Adverse Negative Effects on the Biodiversity 
Conservation and Community Livelihoods in the Greater Virunga Landscape. Unpublished report to Greater Virunga Transboundary Collaboration, Wildlife Conservation Society, New York, USA.

Plumptre, A.J., Nixon, S., Kujirakwinja, D.K., Vieilledent, G., Critchlow, R., Williamson, E.A. et al. (2016b) Catastrophic decline of world's largest primate: $80 \%$ loss of Grauer's gorilla (Gorilla beringei graueri) population justifies Critically Endangered status. PLOS ONE, 11, e0162697.

Plumptre, A.J., Ayebare, S., Segan, D., Watson, J. \& Kujirakwinja, D. (2017) Conservation Action Plan for the Albertine Rift. Wildlife Conservation Society Report to Governments of Uganda, Rwanda, Burundi, Tanzania and Democratic Republic of the Congo. Wildlife Conservation Society, New York, USA.

Possingham, H.P., Ball, I.R. \& Andelman, S. (2000) Mathematical methods for identifying representative reserve networks. In Quantitative Methods for Conservation Biology (eds S. Ferson \& M. Burgman), pp. 291-305. Springer, New York, USA.
Pressey, R.L., Watts, M.E., Ridges, M. \& Barrett, T.W. (2005) C-Plan Conservation Planning Software, User Manual. New South Wales Department of Environment and Conservation, Sydney, Australia.

Saenz, S., Walschburger, T., Gonzales, J.C., Leon, J., McKenny, B. \& Kiesecker, J. (2013) Development by design in Colombia: making mitigation decisions consistent with conservation outcomes. PLOS ONE, 8, e81831.

Stattersfield, A.J., Crosby, M.J., Long, A.J. \& Wege, D.C. (1998) Endemic Bird Areas of the World: Priorities for Biodiversity Conservation. BirdLife International Conservation Series No. 7. BirdLife International, Cambridge, UK.

Tull, D. (2006) China's engagement in Africa: scope, significance and consequences. The Journal of Modern African Studies, 44, 459-479.

Warren, D.L., Glor, R.E. \& Turelli, M. (2010) ENMTools: a toolbox for comparative studies of environmental niche models. Ecography, $33,607-611$. 